\title{
Spatial Images and Changes in their Graphic Representation in Primary and Lower Secondary School Students
}

\author{
Petr Šimáček, Klára Paloušková and Jan Hercik \\ Palacký University Olomouc
}

\section{Abstract}

Depiction of a geographical area through drawings is an individual ability, significantly variable over time. The essential development of such ability can primarily be observed during the period starting from what is termed younger school age to the period of pubescence. This study presents the results of a research focused on monitoring the development of the ability of students aged between 6 and 15 to reproduce their mental image of a well-known geographical area in the form of a drawing (cognitive or mental map). The research was carried out by the method of analyzing the drawings of comparative mental maps produced by primary and lower secondary school students. The data obtained from the research were then statistically evaluated on the basis of selected criteria in order to find identical or different stereotypes in the drawings. Research results point to the existence of significant differences in the ability to graphically illustrate a wellknown geographical space, reflecting, in particular, the age (or degree of experience gained) and, to a lesser extent, the gender. Such findings are important from the pedagogical point of view, because the creation of graphic representation of a certain area belongs to the basic geographical competencies of students.

Keywords: drawing; mental map; perception of space; primary and lower secondary school; spatial concept development

\section{Introduction}

The ability of an individual to create simple drawings to illustrate a certain geographical area is very individual and is influenced by a number of factors. According to Wiegand (2006), a major development of these abilities can mostly be observed during the period 
of compulsory schooling (6-15 years, roughly equivalent to period from the first to the ninth grade of primary and lower secondary school), when there is a significant development of the child's psyche, cognitive and affective abilities, as well as acquisition of geographic, artistic, and other competencies that influence spatial concepts and the ability to reproduce them. Knowing the development of child's abilities is very important in terms of teaching practice. The ability to work with real space or to map it is one of the basic output geographical competences of students (Reinfried, in Haubrich, 2006).

\section{Development of spatial perception in children}

In simple terms, people are not born with spatial orientation. They gain it over time on the basis of their everyday experience with space. An individual becomes acquainted with geographical space gradually, and gains spatial perception during his or her development (see, for example, Hanus \& Marada, 2013; Kitchin \& Blades, 2002; Piaget, 1930; Piaget \& Inhelder, 1967; Vágnerová, 2001). At the beginning, a baby cannot distinguish anything in space, not even itself (Tuan, 1977). Smith et al. (2009) point to the fact that between eighteenth and twenty-fourth months of age, the child develops the ability to recognize geometric shapes and combine a generalized representation of an object with reality. This is confirmed by Piaget \& Inhelder (1967), who found that children at the earliest stages of development show signs of sensory-motor skills. These abilities develop faster than intelligence itself. A very small child is thus able to distinguish objects of different shapes. Tuan (1977) describes the ability of two-anda-half-year-old children to distinguish basic spatial terms (e.g., here and there), and Plumert et al. (1995) describe the ability of three-year-old children to describe the location of an object within a space.

Later stages of the development of spatial perception were explored by Gerber (1981), who found that students of younger school age still lacked the capability to perform abstraction, often manifested as failure to capture a space from a top view (a "bird's eye view") when drawing sketches of a map.

According to some authors (e.g., Catling, 1998; Liben \& Downs, 1994; Matthews, 1984a), children often fail to maintain a consistent way of projecting the spatial perspective and the same scale throughout the drawing. They agree that children under the age of eight tend to capture a space from the side view (as they see it from their own perspective), while children over ten years tend to draw a plan-like form of space (a "bird's eye view"). Children aged between eight and ten years often use both ways of drawing a perspective within one map.

This fact is also confirmed by Piaget \& Inhelder (1967), who distinguished basic phases of the child's conceptualization of space. Based on that, Catling (1978) described developmental stages of graphic representation of space by children. The first stage, topological, occurs in children up to 7 years of age. Depiction of space is strongly 
egocentric, with random arrangement of disproportional elements and mostly drawn as a side view. The second stage, projective, occurs in children aged between 8 and 11 years. During this stage, the egocentric view is gradually diminished, the arrangement of elements in space is better, as well as proportionality of elements. Gradually, it is possible to a greater extent to see depiction of objects in a perspective. The third stage, Euclidean, occurs in children above 11 years of age. Depiction of space is quite objective, with (more or less) adequate arrangement and proportionality of individual elements mostly drawn as top view. Moreover, schematization occurs to a greater extent than in previous stages. The above mentioned age ranges can slightly vary in dependency on various factors, thus they cannot be understood dogmatically.

Uttal et al. (2006) found that eight-year-old children are able to properly process information obtained from a "bird's eye view", but they cannot combine verbal information about space to produce a map. Unlike older children and adults, eightyear-old children need to observe a graphic representation of the spatial situation to be able to understand the spatial relationships. Ondracek and Allen (2000) came to similar conclusions in their study. Although eight-year-old children demonstrably have the ability to remember a description, they cannot convert this description into a coherent model or representation of the space being described.

Other studies approach the research into the development of the perception of space from the opposite perspective. DeLoache (1987) verified the development of children's ability to understand the symbolic relationship between a map or photos and the space they are meant to represent. In an experiment, the child was asked to find an object (toy) hidden in a room using a map or other picture guide. The results showed that three-year-old children can succeed in this task, i.e. they can understand the relationship between a model and a room. When using a photo guide, even twoand-a-half-year-old children can succeed in some circumstances.

Spatial concepts and spatial information can be obtained from more than one source, but usually it is obtained through educational process or own experience (Lane et al., 2019; Schubert, 2016). A person creates their own image of the space in which they move and create a subjective relationship to it (Siwek, 2011). The space surrounding the individual is then perceived by several general elements, such as direction and distance (Siwek, 2011). Thanks to these elements, the individual is orientated in space, with the image of perception of space in their consciousness being a cognitive (mental) map. According to Downs and Stea (2011, p. 312), "cognitive mapping is a process consisting of a series of psychological transformations by which an individual acquires, codes, stores, recalls and decodes information about the relative locations and attributes of the phenomena in his everyday spatial environment."

\section{Mental map}

The mental map concept was first applied in psychology and, because of its interdisciplinary nature, it was later also utilized in sociology, cartography and geography 
(Lloyd, 1989). The geographical approach to the concept may be demonstrated through the view of Tuan $(1975$, p. 209), who understands a mental map as a "special kind of image related directly to sensory experience": "A mental map is a special type of image that is even less directly related to the sensory experience". Drbohlav (1991, p. 164) describes a mental map as a "graphical (cartographic or schematic) expression of human images of the geographical space, most often about its quality or layout". According to Osman (2016), however, a mental map can also be understood as a generalizing term covering various ways of organizing spatial knowledge. A mental map can then be understood as a projection of space in the mind of an individual (in which case it is also referred to as a cognitive map) and also as a cartographic output in the form of a graphic representation. Such representation then captures the image of what, in a given image of the space, is subjectively important and significant for the individual (Šerý \& Šimáček, 2012).

Considering the relation of a phenomenon to the objective reality, mental maps can be divided into comparative and preferential types (Gould \& White, 1993). A preferential mental map contains qualitative assessment judgments. The output of this mental map cannot be compared to reality because it records the individual's preferences. On the other hand, a comparative mental map (which is used in the context of the present research) is related to reality and therefore its accuracy and consistency with reality can be objectively evaluated (Siwek, 2011).

Uttal et al. (2006) concluded in their research that the ability to use a map can help a child to understand and overcome the limits of his/her perception of space. Using maps and creating mental maps also leads the child to spontaneous reflection on how the newly perceived spatial information can be organized into a map, which develops other competencies of the child. The mental map of each individual develops throughout their life. Boulding (1956) describes three possibilities of the development of the level of information about the environment. A person gradually, mostly during pubescence, acquires information about the environment, his/her knowledge is deepened and amended with various pieces of information, and the mental map of space is continuously enriched. Abrahamsson (1999) claims that the comprehensiveness of a mental map depends on the amount of experience with the space and the extent of mobility within this space. The stage during which an individual is not getting any new information and the information already gained is only confirmed in direct experience of the space is referred to by Boulding (1956) as zero development. If the experience of the space is not repeated, the amount of information gained from the mental map gradually decreases over time.

Organizing space in the mind helps us to find out more about the relationship between the basic human ability to learn about the environment and the behavior of humans. Mental maps help us to find out more about the basic human ability to learn about the environment and provide an insight into how people represent the environment and how they behave (Kitchin \& Blades, 2002). 


\section{Research focus and research questions}

Activities such as drawing pictures, graphs or maps can activate cognitive abilities of students ( Višnić et al., 2017). Like other research studies aimed at gathering information through children’s sketches (e.g., Ahi, 2017; Bláha \& Pastuchová Nováková, 2013; Catling, 1998; Gillespie, 2010; Matthews, 1984b; Schubert, 2014) this paper also reflects the importance of children's drawing, which can help them go through the educational process better.

At the age of approximately six, the cognitive ability of the child is markedly improved, and the child begins to perceive the world realistically (Langmeier \& Krejčíŕová, 2006), which can be considered as the first prerequisite for the subsequent description and drawing of this reality. It is only the following years, when the child gradually develops other abilities, such as abstraction, schematization, etc., which significantly influence the resulting form of the reality captured in a form of a mental map. For these reasons, only children aged six years or more from standard primary and lower secondary schools were involved in the research. A certain risk in the realization of this research could be a higher proportion of students with specific learning disabilities, such as Asperger's syndrome, etc., that may have a greater impact on their spatial orientation and creation of mental maps. This risk was eliminated by a consistent selection of the research sample.

When formulating the research questions, the authors followed older works, according to which children create more complex and accurate maps on the basis of increasing age and experience (e.g. Piaget \& Inhelder, 1967). However, age may not be the only factor in this respect. Webley (1981), Montello et al. (1999), Huynh et al. (2010), and Anacta and Bartoschek (2014) point to possible differences in mental mapping depending on gender. In the context of the above-mentioned studies, the main goal of the paper is to contribute to the existing research experience of the creation of spatial representation in children's minds and the development of their ability to represent it graphically while at school age and in pubescence through their own mental sketch maps. Can the dependence between the drawn representation of space and child's age be confirmed? Another question is whether the degree of dependence of these abilities on gender presented by, for example, Webley (1981), is really so significant.

\section{Methods}

\section{Background of research}

Theoretically, the present research can be anchored in the field of geographic phenomenology, which focuses from different angles on the study of the everyday practices of individuals in a space (Gregory et al., 2009); in this case the individuals are primary and lower secondary school students. The perceived phenomenon is a space that each student views in his/her own subjective way. 
A qualitative assessment of mental mapping of a space that is well known to the children became the main research method. According to Frantál et al. (2017, p. 238), "mental mapping is a valuable tool for understanding how humans perceive and reflect their environment... reveals an individual's spatial cognition of a landscape that is the reflection of a mental construction of spatial arrangements in memory sketched on paper". An oftmentioned disadvantage of this method of mental mapping is the ability to visualize the environment, i.e. the content of the mental map can be influenced by the memory of the respondent (Mark et al., 1999). This is confirmed by Golbeck et al. (1986), who claim that the ability to visualize a given space improves with a higher frequency of visits to such a space. That is why the students were asked to draw an environment for which everyday repetition of the spatial experience is guaranteed. In addition, Lilley (2000) points to the fact that the creation of a mental map is not determined only by the respondent's ability to understand the landscape, because a mental map is a creative process in which the respondent's drawing abilities are decisive. Therefore, in the research, none of the criteria directly assess the artistic value of the drawing, since the students were neither required nor expected to duplicate reality in terms of the accuracy of their images. Despite these shortcomings in conducting mental map research, this method is used relatively often because it is considered to be reliable for gathering information about a given environment (Blades, 1990). For this reason, the qualitative analysis of the comparative mental maps created by the students, which was subsequently evaluated on the basis of several selected criteria, became a principal method in the realization of our research.

One can find a number of various forms of evaluation of mental maps in the professional literature. Klett and Alpaugh (1976) identified a number of valuable map attributes, such as the scale or perspective of the drawing. Harwood and Usher (1999) classified maps according to five criteria: accuracy of spatial layout, proportion of drawn elements (scale), layout perspective, level of abstraction of the drawing, and the way the symbology was expressed. Lynch (1960), on the other hand, focused on groups of objects that are constantly repeated in mental maps. The respondents attribute the greatest importance to these objects and thus create an image of the geographical space in cities. These groups are divided into the following groups: districts (e.g. residential areas), paths (e.g. streets), edges (barriers such as, e.g. a river), nodes (e.g. railroad stations), and landmarks (e.g. important buildings). On the basis of these Lynch's groups, Gillespie (2010) built her own analysis of mental maps. In her research she replaced a group of social nodes by socialization, i.e. any indicator or image showing interaction between humans. She further extended the evaluation of mental maps by the use of criteria monitoring the relationship between children and the drawn environment. According to her research, the child distinguishes those elements that are really important in his/her image of the space, either by elaborate details or by emphasizing the size of the elements in relation to the rest of the sketch. Another one 
of numerous frequently used assessment criteria for the analysis of mental maps is the frequency of the drawn elements. In studies such as those carried out by Matthews (1984a), Kynčlova et al. (2009) or Bláha \& Pastuchová Nováková (2013), this frequency was used to identify the most significant elements perceived by students, as well as for identification of certain specific differences between partial groups of students.

\section{Sample of research}

The necessary data (students' mental maps) were obtained by means of a survey at Šumperk Primary School, where a total of 174 students (104 boys and 70 girls - see Table 1) were involved in the survey.

Table 1

Structure of students by class and gender

\begin{tabular}{lrrrrrrrrrr}
\hline Class & \multicolumn{1}{c}{ I } & \multicolumn{1}{c}{ II } & III & IV & \multicolumn{1}{c}{ V } & VI & VII & VIII & IX & total \\
\hline Boys & 12 & 9 & 12 & 10 & 9 & 11 & 11 & 16 & 14 & 104 \\
Girls & 7 & 8 & 8 & 6 & 8 & 10 & 9 & 8 & 6 & 70 \\
Total & 19 & 17 & 20 & 16 & 17 & 21 & 20 & 24 & 20 & 174 \\
\hline
\end{tabular}

For the purpose of the evaluation of the research, the individual years were subsequently grouped into three-year groups (the classes from first to third, from fourth to sixth, and from seventh to ninth year). The underlying premise for this division was adopted from the basic developmental stages of human life from ontogenetically conceived developmental psychology: younger school age, older school age, and pubescence (Langmeier \& Krejčírová, 2006), corresponding to developmental degrees of spatial thinking according to Stückrath (1963) or development of spatial abilities according to Piaget \& Inhelder (1967), with regards to the structure of the national education system. The ability of perception and representation of individual components of geographical space and the links therein are significantly different between these developmental stages, that is, between age groups. Gradually, there is a shift from a markedly egocentric understanding of space with random arrangement of its parts, without understanding the relations, correct distribution and proportion of the elements, to representation from above, with substantially improved position, size, distances and proportionality (Catling 1978; Stückrath, 1963).

The research was carried out at the beginning of 2015. In the first stage, the school principal was approached with a request to allow the research to be carried out; the specific dates were then arranged with the class teachers, and the survey was not focused on a specific school subject.

\section{Specification of research task}

First, the pilot study was conducted, in which 15 students aged from 6 to 12 participated. The students were asked about their knowledge of different parts of the town. Then they were given the task to draw maps of these localities. It was previously decided that the results of this pilot study would not be included in the later evaluation of the 
main research, so it was possible to carry out the pilot study in a more qualitative way (creating an opportunity to have a discussion with the children and ask additional questions to verify the actual knowledge of different localities and the ability to draw the intended elements). The original intention was to evaluate the students' spatial image based on a mental map of the town park, since it is located near the school, and there was an assumption that most of the students in the school would have already visited this park. However, it turned out that only a small percentage of students knew this park, and that they did not know anything about the originally selected localities either. The main research would have been too greatly affected by this and therefore it was necessary to change the selected locality. Finally, it was decided that students would draw the grounds of their school, which allowed them to draw an environment that was well known from the repeated, almost everyday spatial experience. On the basis of the pilot study, the time needed to conduct the research in classes was also defined.

Within the main research students were asked to draw their mental images of the spatial arrangement of the school grounds. The wording of the request to draw a mental map was as follows: "Draw as best as you can what is found on the grounds of your school; try to show me that you know this space." In addition, the students were instructed to describe the drawn elements thoroughly. Students were not provided with any specific answers to their supplementary questions, so the concept of the task itself was up to the students. No time limit was set for the students to draw a mental map; however, the research was limited to a maximum of 45 minutes of a lesson. To ensure that the results could not be influenced by the paper format of the map, a standard sheet of A4 white paper was distributed to all the students. On the basis of the assumptions of the presented research, a simple questionnaire was attached to the sheet on which a mental map was to be drawn. The students were asked to fill in several basic identifiers which could be used to monitor the influence of the individual characteristics of the respondents on the characteristics of their mental maps. The whole questionnaire was completely anonymous, collecting data on gender, age, and permanent residence.

\section{Analysis of mental maps}

The evaluation of mental maps used in this paper is based on the classification schemes described in similarly oriented research studies (see above). In order to identify the common and distinct features of the students' mental maps, their evaluation was performed on the basis of fourteen criteria (see Table 2) and the three major criteria were further analyzed in more detail. The selected criteria allow the basic contours of the space concept's development to be evaluated; from this point of view, other criteria are rather complementary information, as well as information on the way in which the maps were drawn.

The number and focus of the evaluation criteria were designed to cover as much information obtainable from the sketches as possible. The aim of the evaluation was to 
capture the qualitative and quantitative changes in the perception of space associated with the individual's development - the way the individual converts his/her mental image into a map, and what elements he/she considers to be key in the space and therefore also suitable for drawing on the mental map.

Table 2

Criteria for evaluating the sketches of mental maps (the three major criteria are in bold and italics)

\begin{tabular}{|c|c|c|c|}
\hline \multirow{2}{*}{$\begin{array}{l}\text { Criterion } \\
\text { Delimitation of the plot }\end{array}$} & \multicolumn{3}{|c|}{ Criterion Category } \\
\hline & Whole & Partial & Incomplete \\
\hline Number of perspectives & One & More & - \\
\hline Perspective of the buildings & Side view & $\begin{array}{l}\text { Oblique } \\
\text { projection }\end{array}$ & Top view \\
\hline Level of schematization & Low & Middle & High \\
\hline Number of elements drawn & A few & $\begin{array}{l}\text { Only main } \\
\text { elements }\end{array}$ & $\begin{array}{l}\text { Including } \\
\text { details }\end{array}$ \\
\hline Spatial arrangement of the plot on the paper & $\begin{array}{l}\text { Proper } \\
\text { composition }\end{array}$ & $\begin{array}{l}\text { Improper } \\
\text { composition }\end{array}$ & - \\
\hline Label orientation & $\begin{array}{l}\text { In one } \\
\text { direction }\end{array}$ & $\begin{array}{l}\text { In more } \\
\text { directions }\end{array}$ & - \\
\hline View & North-south & Other & - \\
\hline Size of the elements drawn & $\begin{array}{l}\text { Corresponds to } \\
\text { reality }\end{array}$ & $\begin{array}{l}\text { Corresponds } \\
\text { partially to } \\
\text { reality }\end{array}$ & $\begin{array}{l}\text { Does not } \\
\text { correspond } \\
\text { to reality }\end{array}$ \\
\hline Layout of the elements in the plot & $\begin{array}{l}\text { Corresponds to } \\
\text { reality }\end{array}$ & $\begin{array}{l}\text { Corresponds } \\
\text { partially to } \\
\text { reality }\end{array}$ & $\begin{array}{l}\text { Does not } \\
\text { correspond } \\
\text { to reality }\end{array}$ \\
\hline Usage of color & Yes & No & - \\
\hline Social elements (figures in the map) & Yes & No & - \\
\hline Natural elements (animals and plants) & Yes & No & - \\
\hline Means of transport & Yes & No & - \\
\hline
\end{tabular}

In terms of statistical processing, the students' characteristics, such as age (or degree of experience) and gender, as well as the three criteria selected for the assessment of the partial aspects of the obtained mental maps, played a significant role. On the basis of the first criterion selected - the number of perspectives used - the maps were divided in a dichotomous way into sketches that contained only one perspective on the objects that were drawn and those where the objects were drawn from multiple perspectives. Under the second criterion - the perspective used for the buildings - a particular predominant way of drawing the buildings was assessed, i.e. a side, oblique, or top view. The third criterion - the level of schematization - categorized the maps into those that showed a low, medium, or high degree of schematization of the objects that were drawn (see Figure 1). Due to the nature of the data, the Cramer coefficient, the Spearman coefficient, and the Phi coefficient were used to evaluate interdependencies. 


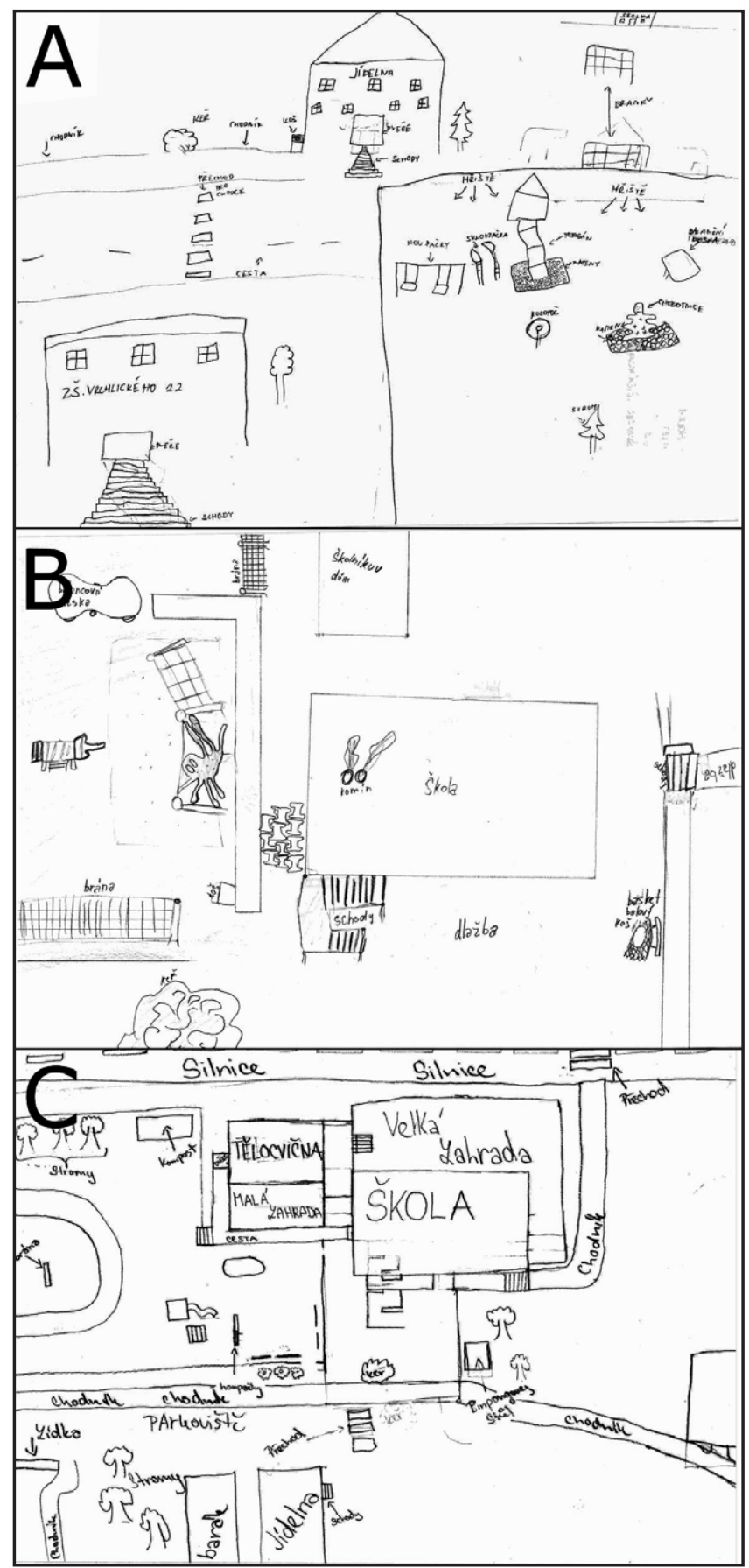

Figure 1. The level-of-schematization categories through the example of particular maps

Note: A - low level of schematization (a student in the third grade); B - medium level of schematization (a student in the fifth grade); $\mathrm{C}$ - high level of schematization (a student in the eighth grade). 


\section{Results}

Based on the evidence of the research that was carried out, there was a significant difference in representations of space between the students in different age groups. The number of perspectives used was the first evaluation criterion. A total of 106 students (61\% of all the participants) drew the map from one perspective. With regard to the categories of the "number of perspectives" criterion that were monitored, this was therefore the predominant way used to represent perspective. On closer inspection, it can be seen that it was used by $66 \%$ of students in the first to third grades, while among the students in the fourth to sixth grades this category was recorded in $61 \%$ of cases, and in the group of the oldest students it was as much as five percentage points less. In terms of gender, there were 71 boys in this category (68\% of all the participating boys) and 35 girls (50\% of all the participating girls).

The most frequent way in which the buildings were represented was the ground plan, which was chosen by 103 students (over 59\% of all those participating). On the other hand, only about $5 \%$ of the students chose an oblique view of the space that was drawn. The ground plan appeared most frequently in the group of students in the seventh to ninth grades, specifically in $94 \%$ of cases, whereas in the group of students in the fourth to sixth grades the percentage was $59 \%$ and in the youngest group only $20 \%$. When gender is taken into account, 65 boys ( $63 \%$ of all the participating boys) and 38 girls (54\% of all the participating girls) chose the ground plan.

Although almost $37 \%$ of all the participating students fall into the oldest age group, with a very high percentage of students with a high degree of schematization of the drawing (84\%), the percentage of this category in the whole sample was lower than $22 \%$. The level of schematization with the greatest representation was the middle one, chosen by 84 students ( $48 \%$ of all the participants). From a gender perspective, the schematic level can be evaluated as follows: a total of 24 boys (23\% of all the participating boys) and 28 girls (40\% of all the participating girls) made their sketches with a low level of schematization. A high level of schematization was recorded in approximately the same percentage of boys (27\%), while in the girls this percentage dropped dramatically, to $14 \%$.

The calculated values of the coefficients used (and also $p$-values), on the basis of which we evaluated the strength and the statistical significance of the dependences between individual characteristics of the students and the selected criteria for the evaluation of the mental maps, are shown in Table 3.

Statistically significant dependences on the significance level of .05 can only be seen in five entities; however, the strength of the dependence varies significantly in these cases. In this respect, the strongest dependence was recorded between the level of schematization and the student's age (that is, the degree of experience gained), followed by the perspective used and the age of the students. On the other hand, dependences between gender and selected criteria seem to be rather weak. From this point of 
view, the only criterion (number of perspectives drawn) was evaluated as significant, because sketch maps created by boys showed a higher degree of schematization than the sketch maps created by girls. However, this statistical difference was observed only within the second age group.

Table 3

Determined dependences between students' characteristics and selected criteria

\begin{tabular}{ccccccc}
\hline $\begin{array}{c}\text { Criterion / Students' } \\
\text { Characteristics }\end{array}$ & \multicolumn{2}{c}{$\begin{array}{c}\text { Number of } \\
\text { Perspectives }\end{array}$} & \multicolumn{2}{c}{$\begin{array}{c}\text { Perspective of } \\
\text { Buildings }\end{array}$} & \multicolumn{2}{c}{$\begin{array}{c}\text { Level of } \\
\text { Schematization }\end{array}$} \\
\hline Age Group & Cramér & $p$-value & Cramér & $p$-value & Spearman & $p$-value \\
\hline & .083 & .546 & .467 & .000 & .574 & .000 \\
\hline Phi & $p$-value & Cramér & $p$-value & Cramér & $p$-value \\
\hline Gender & -.184 & .015 & .139 & .198 & .204 & .027 \\
of which age group: & & & & & & .285 \\
classes I-III & -.092 & .492 & .120 & .680 & .103 \\
classes IV-VI & -.357 & .009 & .189 & .403 & .165 & .481 \\
classes VII-IX & -.127 & .309 & .076 & .545 & .221 & .211 \\
\hline
\end{tabular}

\section{Discussion and conclusions}

In a comprehensive view of the mental maps created by the students, it is possible to identify very well the significant transformation of the students' ability to create mental maps, i.e. representation and perception of the individual elements in a space, between the age of 6 and 15. It has already been mentioned, for example, by Piaget \& Inhelder (1967) or Catling (1978). We can find several reasons for this. In addition to the significant development of the psychological aspect of children in the period under review, which is also related to the gradual development of the abilities to perform abstraction, schematization, and generalization, another significant cause can be seen in the gradually directed familiarization of students with geographical space and a map as the most frequent means used to depict it within the school lessons from the fourth (entry into the Projective stage) and, more significantly, from the sixth (allowing entry into the Euclidean stage) grade. This change can easily be seen in Figure 2. In comparison of this study's findings and the study of Piaget and Inhelder (1967), differences can be seen in declared age, when children should pass from one stage to another. According to Piaget and Inhelder (1967), children should pass to the next developmental stage approximately 1-2 years earlier than was found in this study. There can be many reasons for this, but they are most likely to be manifested due to the specifics of the formal education system, including a different approach to the geographical curriculum. 


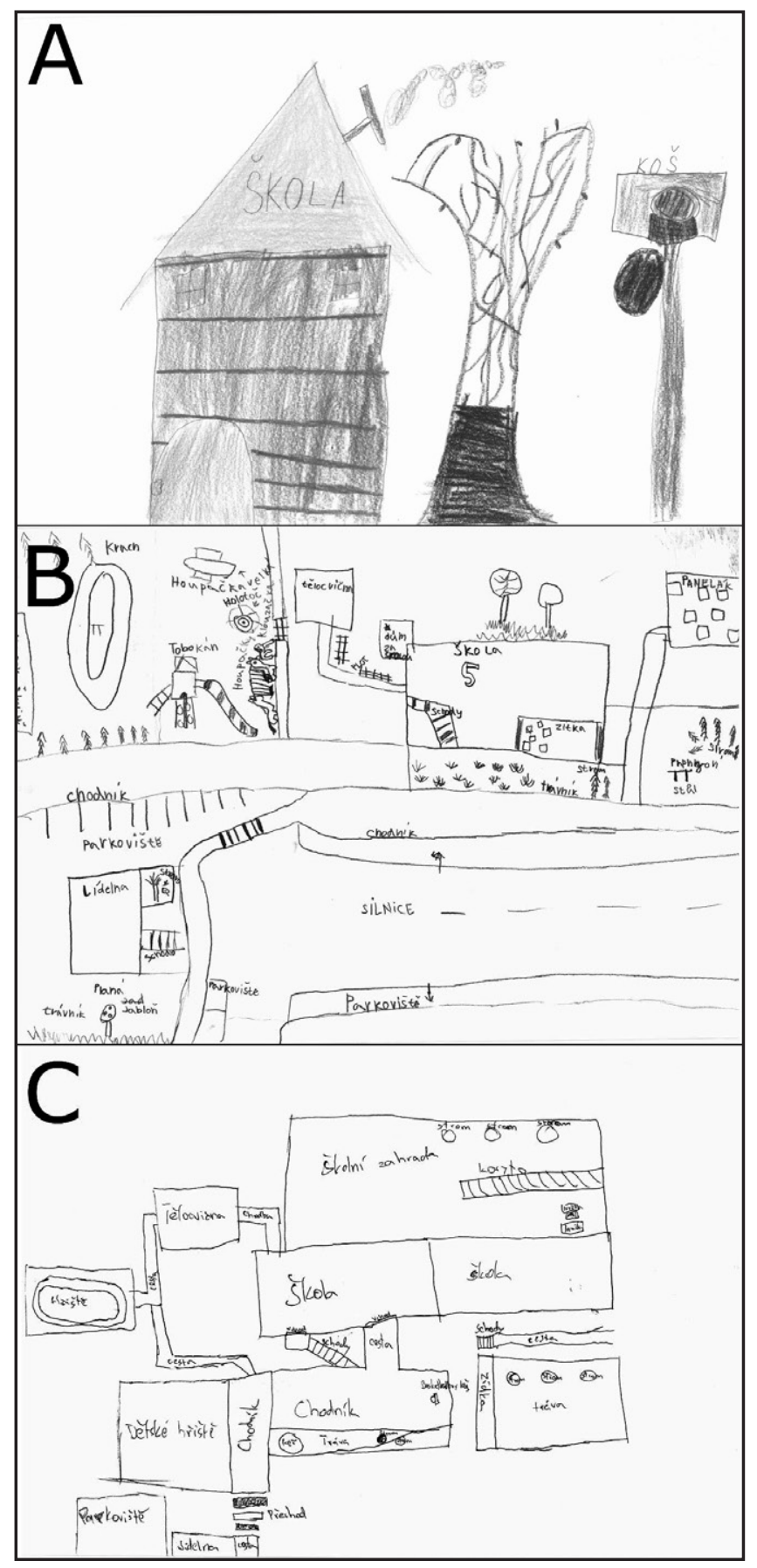

Figure 2. Examples of changes in drawing a given space, depending on age (degree of experience)

Note: A - a student in the second grade (8 years old); B - a student in the fourth grade (10 years old); C - a student in the eighth grade ( 13 years old). 
The research shows that, depending on the increasing age of students, the degree of schematization of the images increases significantly and the types of perspectives used by the students in drawing buildings change. While the youngest students in the first to third grades most often preferred a side view of buildings in their drawings, as their age increased, a top view started to prevail and in the students in the ninth grade it was dominant. This conclusion confirms one of the basic findings of, for example, Gerber (1981) about the marked connection between the development of abstraction and the ability to produce a top view. An interesting finding by some authors, such as Matthews (1984b), Liben and Downs (1994), and Catling (1998), about the inconsistency of the representation of spatial perspective in students of the same age throughout the drawing was only partially confirmed by the present research, in the girls in the fourth to sixth grades (aged 9 to 11).

Similarly (although not so significantly), a direct dependence was found between the increase in the students' age and the level of schematization of the drawing. As in the previous case, this finding can be justified by the gradual development of the capability of abstraction, as suggested by Gerber (1981). However, in the present research, significant unevenness was identified in the development of the level of schematization, where a large difference between the first and fourth and fifth and ninth grades can be seen. A deeper study of national curricula and school syllabi revealed a direct link between the increase in the level of schematization between the fourth and fifth grade and the beginning of systematic geographic education, which, in the Czech education system, most frequently begins in this period. With the increasing targeted development of the geographic and cartographic competencies of students during the period from the sixth to ninth grades, as mentioned by Hanus and Marada (2013) or marginally by Knecht and Hofmann (2013), the level of schematization of the drawing increases.

Regarding the dependencies of the observed criteria on the gender of the child, the results are not so statistically significant and in some cases, to a large extent, they do not confirm the conclusions reached by Webley (1981), Huynh et al. (2010) or presented in some other studies. However, it should be emphasized that, for example, Webley (1981) only worked with a group of eight-year-old students in his research and Huynh et al. (2010) based their research on gender differences in adults. The only criterion where this gender dependency is statistically significant is the level of schematization of the drawing, where the drawings created by boys show a higher degree of schematization than the drawings created by girls. However, this finding only applies if we take the entire research sample as a whole. In the case of deeper internal examination of individual age groups, no statistically significant differences in the degree of schematization between the boys and girls were recorded. A more detailed study of possible differences in the level of schematization among the girls and boys within defined age groups did not confirm any statistically significant dependences. Considering the gender differences, the criterion of the number of perspectives within 
the given age groups is interesting. While no significant dependence was confirmed in the two outer groups, the dependence was very important for the middle group (fourth to sixth grades). It was found that the boys in this group use only one perspective in their drawings, while the girls are more likely to use more perspectives.

The ability to draw simple mental maps of a well-known territory changes significantly in children during their school years. It is possible to see a change from sketches with a low level of schematization containing mostly side-view representations of objects drawn by six-year-old students to sketches with a high level of schematization and a distinct predominant top view of buildings in pubescent students. This change is due, in particular, to the significant development of some of the child's psychological functions, as well as to the gradual acquisition of new geographic and cartographic competences within formal education. These findings may assist teachers in selecting and formulating geographic educational goals for each class as well as to better identify subsequent achievement of these goals by students.

\section{Acknowledgments}

Authors would like to express thanks to Prof. Danuše Nezvalová for her remarks and recommendations regarding the content of the article as well as to all participating students for their time. This research was supported by the project "Socio-economic structures and determinants of the contemporary landscape: analysis and interpretation of geographic reality" (IGA_PrF_2017_021).

\section{References}

Ahi, B. (2017). The world of plants in children's drawings: color preferences and the effect of age and gender on these preferences. Journal of Baltic Science Education, 16 (1), 32-42.

Anacta, V. J. A., \& Bartoschek, T. (2014). It's girls' day! What sketch maps show about girls' spatial knowledge. In: Connecting a Digital Europe through Location and Place. Proceedings of the AGILE'2014 International Conference on Geographic Information Science, Castellón, 2014. https://agile-online.org/conference paper/cds/agile 2014/agile2014 137.pdf

Blades, M. (1990): The reliability of data collected from sketch maps. Journal of Environmental Psychology, 10 (4), 327-339. https://doi.org/10.1016/S0272-4944(05)80032-5

Bláha, J. D., Pastuchová Nováková, T. (2013). Mentální mapa Česka v podání českých žáků základních a středních škol [Mental map of Czechia rendered by Czech elementary and secondary school students]. Geografie, 118(1), 59-76. https://doi.org/10.37040/ geografie2013118010059

Boulding, K. (1956). The image: knowledge in life and society. Ann Arbor, MI: University of Michigan Press. https://doi.org/10.3998/mpub.6607

Catling, S. J. (1978). The child's spatial conception and geography education. Journal of Geography, 77 (1), 24-28. https://doi.org/10.1080/00221347808980060 
Catling, S. J. (1998). Children as mapmakers. In S., Scoffham (Ed.), Primary Sources: Research Findings in Primary Geography (pp. 10-11). The Geographical Association.

DeLoache, J. S. (1987). Rapid change in the symbolic functioning of very young children. Science, 238 (4833), 1556-1557. https://doi.org/10.1126/science.2446392

Downs, R. M., \& Stea, D. (2011). Cognitive maps and spatial behaviour: Process and products. In Dodge M., Kitchin R., \& Perkins Ch. (Eds.), The map reader: theories of mapping practice and cartographic representation, 1st edition (pp. 312-317). John Wiley \& Sons. https://doi. org/10.1002/9780470979587.ch41

Drbohlav, D. (1991). Mentální mapa ČSFR: definice, aplikace, podmíněnost [Mental map of the CSFR - Definition, application, conditionality]. Sborník České geografické společnosti, 96(3), 163-176.

Frantál, B., Bevk, T., van Veelen, B., Hărmănescu, M., \& Benediktsson, K. (2017): The importance of on-site evaluation for placing renewable energy in the landscape: A case study of the Búrfell wind farm (Iceland). Moravian Geographical Reports, 25(4), 234-247. https://doi.org/10.1515/mgr-2017-0020

Gerber, R. (1981). Young children's understanding of the elements of maps. Teaching Geography, 6(3), 128-133.

Gillespie, C. A. (2010). How culture constructs our sense of neighborhood: Mental maps and children's perceptions of place. Journal of Geography, 109(1), 18-29. https://doi. org/10.1080/00221340903459447

Golbeck, S. L., Rand, M., \& Soundy, C. (1986). Constructing a model of a large scale space with the space in view: Effects on preschoolers of guidance and cognitive restructuring. Merrill-Palmer Quarterly, 32(2), 187-203.

Gould, P., \& White, R. (1993). Mental maps, $2^{\text {nd }}$ edition. Routledge.

Gregory, D., Johnston, R., Pratt, G., Watts, M., \& Whatmore, S. (Eds.) (2009). The dictionary of human geography, $5^{\text {th }}$ edition. Wiley-Blackwell.

Hanus, M., \& Marada, M. (2013). Map skills in Czech and foreign curricula: A comparative study. Geografie, 118 (2), 158-178. https://doi.org/10.37040/geografie2013118020158

Harwood, D., \& Usher, M. (1999). Assessing progression in young children's map skills. International Research in Geographical and Environmental Education, 8(3), 222-238. https:// doi.org/10.1080/10382049908667613

Huynh, N. T., Doherty, S., \& Sharpe, B. (2010). Gender differences in the sketch map creation process. Journal of Maps, 6 (1), 270-288. https://doi.org/10.4113/jom.2010.1081

Klett, F. R., \& Alpaugh, D. (1976). Environmental learning and large scale environments. In G. T. Moore, \& R. G. Golledge (Eds.). Environmental Knowing, Dowden, Hutchinson and Ross.

Kynčlová, M., Hudeček, T., \& Bláha, J. D. (2009). Assessment of cartographic outputs: Analysis of mental maps of orienteering runners. Geografie, 114(2), 105-116. https://doi. org/10.37040/geografie2009114020105

Kitchin, R., \& Blades, M. (2002). The cognition of geographic space. Tauris. https://doi. org/10.5040/9780755620951

Knecht, P., \& Hofmann, E. (2013). K problému řazení geografického učiva ve školních vzdělávacích programech [Geography Curriculum Scope and Sequence in Czech Lower 
Secondary Schools]. Informace ČGS, 32(2), 13-25. https://geography.upol.cz/soubory/ lide/hercik/DIG1/Knecht-Hofmann 2013.pdf

Lane, R., Carter, J., \& Bourke, T. (2019). Concepts, conceptualization, and conceptions in ceography, Journal of Geography, 118 (1), 11-20. https://doi.org/10.1080/00221341.201 $\underline{8.1490804}$

Langmeier, J., \& Krejčířová, D. (1998). Vývojová psychologie, 3. vydání [Developmental psychology, 3rd edition]. Grada Publishing.

Liben, L. S., \& Downs, R. M. (1994). Fostering geographic literacy from early childhood: The contributions of interdisciplinary research. Journal of Applied Developmental Psychology, 15(4), 549-569. https://doi.org/10.1016/0193-3973(94)90022-1

Lilley, K. (2000). Landscape mapping and symbolic form: Drawing as a creative medium in cultural geography. In S. Ryan, S. Naylor, D. Crouch, \& I. Cook (Eds.), Cultural Turns, Geographical Turns: Perspectives on Cultural Geography (pp. 370-438). NJ Prentice-Hall. https://doi.org/10.4324/9781315839165-30

Lloyd, R. (1989). Cognitive maps: Encoding and decoding information. Annals of the Association of American Geographers, 79(1), 101-124. https://doi.org/10.1111/j.1467-8306.1989.tb00253.x Lynch, K. (1960). The image of the city. MIT Press.

Mark, D. M., Freksa, Ch., Hirtle, S. C., Lloyd, R., \& Tversky, B. (1999). Cognitive models of geographical space. International Journal of Geographical Information Science, 13(8), 747774. https://doi.org/10.1080/136588199241003

Matthews, M. H. (1984a). Cognitive mapping abilities of young boys and girls. Geography, 69(4), 327-336.

Matthews, M. H. (1984b). Environmental cognition of young children: Images of journey to school and home area. Transactions of the Institute of British Geographers, 9 (1), 89-105. https://www. jstor.org/stable/pdf/621869.pdf?refreqid=excelsior\%3Aa8f0a8f372e02c0713fbf3c907f82839

Montello, D., Lovelace, K., Golledge, R., \& Self, C. (1999): Sex-related differences and Similarities in geographic and environmental spatial abilities. Annals of the Association of American Geographers, 89(3), 515-534. https://doi.org/10.1111/0004-5608.00160

Ondracek, P. J., \& Allen, G. L. (2000). Children's acquisition of spatial knowledge from verbal descriptions. Spatial Cognition and Computation, 2 (1), 1-30. https://doi. org/10.1023/A:1011449932129

Osman, R. (2016). Sémantická mapa: Příklad Ústí nad Orlicí [Semantic map: The case of Ústí nad Orlicí]. Geografie, 121(3), 463-492. https://www.geografie.cz/archiv/stahnout/35, https://doi.org/10.37040/geografie2016121030463

Piaget, J. (1930). The child's conceptions of the world. Routledge \& K. Paul.

Piaget, J., \& Inhelder, B. (1967). The child's conceptions of space. W. W. Norton \& Company.

Plumert, J. M., Ewert, K., \& Spear, S. J. (1995). The early development of children's communication about nested spatial relations. Child Development, 66(4), 959-969. https:// doi.org/10.1111/j.1467-8624.1995.tb00915.x

Reinfried, S. (2006). Interessen, Vorwissen, Fähigkeiten und Einstellungen von Schülerinnen und Schülern berücksichtigen [Consideration of the interests, preconceptions, skills and 
attitudes of pupils]. In H. Haubrich (Ed.), Geographie unterrichten lernen: Die neue Didaktik der Geographie konkret (pp. 49-78). Oldenbourg Schulbuchverlag.

Schubert, J. C. (2014). Students' preconceptions of the formation and location of deserts: Results of a qualitative interview study with grade 7 students in Germany. Review of International Geographical Education Online (RIGEO), 4(2), 102-119. https://files.eric. ed.gov/fulltext/EJ1158068.pdf

Schubert, J. C. (2016). Raumkonzepte im Kontext geographischen Lernens im Sachunterricht [Spatial concepts in the context of basic geographical education]. In Adamina, M., Hemmer, M., Schubert, J. C. (Eds.), Die geographische Perspektive konkret. Begleitband 3 zum Perspektivrahmen Sachunterricht (pp. 143-146). Klinkhardt.

Siwek, T. (2011). Percepce geografického prostoru [Perception of Geographical Space]. Czech Geographical Society.

Smith, M., Davidson, J., Cameron, L., \& Bondi, L. (2009). Emotion, place and culture. Ashgate Publishing Ltd.

Stückrath, F. (1963). Kind und raum. Psychologische Voraussetzung der Raumlehre in der Volskschule. Kösel.

Šerý, M., \& Šimáček, P. (2012). Perception of the historical border between Moravia and Silesia by residents of the Jeseník area as a partial aspect of their regional identity (Czech Republic). Moravian Geographical Reports, 20(2), p. 36-46. http://www.geonika.cz/EN/research/ ENMGRClanky//2012 2 SERY.pdf

Tuan, Y. F. (1975). Images and mental maps. Annals of the Association of American Geographers, 65 (2), 205-213. https://doi.org/10.1111/j.1467-8306.1975.tb01031.x

Tuan, Y. F. (1977): Space and place: The perspective of experience. Minnesota University Press.

Uttal, D. H., Fisher, J. A., \& Taylor, H. A. (2006). Words and maps: Developmental changes in mental models acquired from descriptions and depictions. Developmental Science, 9(2), 221-235. https://doi.org/10.1111/j.1467-7687.2006.00481.x

Vágnerová, M. (2001). Kognitivní a sociální psychologie žáka základní školy [Cognitive and social psychology of primary school students]. Karolinum.

Vágnerová, M. (2012). Vývojová psychologie: Dětství a dospívání [Developmental psychology: Childhood and Adolescence]. Karolinum.

Višnić, T., Ivanović Bibić, L., Đukičin Vučković, S., Ivkov-Džigurski, A., \& Konečnik Kotnik, E. (2017). The evaluation of the role of teaching aids in stimulating pupils' activation in geography. Journal of the Geographical Institute "Jovan Cvijić"SASA, 67(2), 179-194. https:// doi.org/10.2298/IJGI1702179V

Webley, P. (1981). Sex differences in home range and cognitive maps in eight-year old children. Journal of Environmental Psychology, 14 ), 293-302. https://doi.org/10.1016/ $\underline{\text { S0272-4944(81)80027-8 }}$

Wiegand, P.(2006). Learning and teaching with maps. Routledge. https://doi.org/10.4324/9780203477793 


\section{Petr Šimáček}

Department of Geography

Palacký University Olomouc

17. listopadu 12, 77146 Olomouc, Czech Republic

petr.simacek@upol.cz

\section{Klára Paloušková}

Department of Geography

Palacký University Olomouc

17. listopadu 12, 77146 Olomouc, Czech Republic

klara.palouskova01@upol.cz

\section{Jan Hercik}

Department of Geography

Palacký University Olomouc

17. listopadu 12, 77146 Olomouc, Czech Republic

jan.hercik@upol.cz 


\section{Prostorne slike i promjene u njihovom grafičkom prikazu kod učenika osnovne škole}

\section{Sažetak}

Prikaz geografskoga prostora putem crteža individualna je sposobnost, značajno promjenjiva kroz vrijeme. Temeljni razvoj takve sposobnosti primarno se može promatrati u razdoblju od tzv. mlađe školske dobi do razdoblja puberteta. Ovim radom prikazani su rezultati istraživanja koje se usredotočilo na promatranje razvoja sposobnosti učenika između 6. i 15. godine u stvaranju mentalne slike poznatoga geografskog područja, u obliku crteža (kognitivna ili mentalna karta). Istraživanje je provedeno analizom crteža usporednih mentalnih karata koje su napravili učenici osnovne škole. Podatci dobiveni istraživanjem zatim su statistički vrednovani na temelju određenih kriterija, kako bi se pronašli isti ili različiti stereotipi među crtežima. Rezultati istraživanja upućuju na postojanje značajnih razlika u sposobnosti grafičkoga prikazivanja poznatoga geografskog prostora, osvrćući se konkretno na dob (ili stupanj stečenoga iskustva) ili, u manjoj mjeri, i na spol učenika. Takvi ishodi su bitni s pedagoškoga stajališta jer rad s geografskim prikazom određenoga područja pripada osnovnim geografskim kompetencijama učenika.

Ključne riječi: crtež; mentalna karta; osnovna škola; percepcija prostora; razvoj prostornoga koncepta

\section{Uvod}

Sposobnosti pojedinaca da stvore jednostavan crtež kojim bi se prikazalo određeno geografsko područje, vrlo su individualne i pod utjecajem mnogobrojnih čimbenika. Prema Wiegandu (2006), veći razvoj tih sposobnosti može se promatrati uglavnom tijekom razdoblja obveznoga školovanja (6.-15. godine, što je ekvivalentno razdoblju od prvoga do devetoga razreda osnovne škole). Tada se značajno razvija dječja psiha, kognitivne i emotivne vještine te se stječu geografske, umjetničke i druge kompetencije koje utječu na prostorne koncepte kao i mogućnosti njihova stvaranja. Poznavanje razvoja dječjih sposobnosti od iznimne je važnosti u pogledu nastavne prakse. Sposobnost rada sa stvarnim prostorom ili sposobnost njegovoga prijenosa na kartu predstavlja jednu od temeljnih geografskih kompetencija učenika. 


\section{Razvoj prostorne percepije kod djece}

Jednostavno rečeno, ljudi se ne rađaju s prostornom orijentacijom, već ju stječu kroz vrijeme na temelju njihova svakodnevnoga iskustva s prirodom. Pojedinac postupno upoznaje geografski prostor te kroz vlastiti razvoj dobiva prostornu orijentaciju (Hanus i Marada, 2013; Kitchin i Blades, 2002; Piaget, 1930; Piaget i Inhelder, 1967; Vágnerová, 2001). U početku, dijete ništa ne može razlikovati u prostoru, čak ni samo sebe (Tuan, 1977). Smith, Davidson, Cameron i Bondi (1967) upućuju na činjenicu da između osamnaestoga i dvadesetčetvrtoga mjeseca života, dijete razvija sposobnost prepoznavanja geometrijskih oblika te povezivanja općega prikaza objekta sa stvarnošću. To su potvrdili i Piaget i Inhelder (1967) koji su otkrili da djeca u najranijoj dobi razvoja pokazuju znakove osjetilno-motoričkih vještina. Takve vještine razvijaju se brže od same inteligencije, zbog čega je jako malo dijete sposobno razlikovati predmete različitih oblika. Tuan (1977) opisuje kod djece od dvije i pol godine sposobnost razlikovanja osnovnih prostornih izraza (npr. ovdje i ondje), a Plumert i dr. (1995) kod djece od tri godine sposobnost opisivanja lokacije predmeta unutar prostora.

Kasnije faze razvoja percepcije prostora istraživao je Gerber (1981), koji je otkrio da učenicima mlađe školske dobi ipak i dalje nedostaje sposobnost razumijevanja apstrakcije, što se često manifestira kao neuspjeh snimanja prostora s visine (tzv. „ptičja perspektiva") prilikom skiciranja karte.

Prema nekim autorima (npr. Catling, 1998; Liben i Downs, 1994; Matthews, 1984a) djeca često ne uspiju zadržati dosljedan način projiciranja prostorne perspektive i iste ljestvice tijekom crtanja. Slažu se u tome da su djeca mlađa od osam godina sklona crtanju prostora sa strane (kako ga vide iz svoje perspektive), dok su djeca iznad deset godina sklonija crtanju prostora nalik planu („ptičja perspektiva”). Djeca u dobi između osam i deset godina često koriste oba načina prikaza perspektive unutar jedne karte.

Tu su činjenicu također potvrdili Piaget i Inhelder (1967), koji su utvrdili razlike osnovnih faza djetetove konceptualizacije prostora. Na temelju toga je Catling (1967) kod djece opisao razvojne faze grafičkoga prikaza prostora. Prva faza - topološka - javlja se kod djece do sedam godina starosti. Prikazivanje prostora izrazito je egocentrično, sa slučajnim rasporedom neproporcionalnih elemenata te je uglavnom crtano $s$ bočnoga pogleda. Druga faza - projekcijska - javlja se kod djece u dobi između od osam i jedanaest godina. Tijekom ove faze egocentrični pogled postupno se smanjuje, raspored elemenata u prostoru je ispravniji kao i proporcionalnost elemenata te je postupno u većoj mjeri moguće vidjeti predmete u određenoj perspektivi. Treća faza - euklidska - javlja se kod djece starije od jedanaest godina. Prikazivanje prostora prilično je objektivno s (više ili manje) adekvatnim rasporedom i proporcionalnošću pojedinih elemenata te se uglavnom crta kao tlocrt. Štoviše, shematizacija se događa u mnogo većem obujmu nego u prethodnim fazama. Gore navedene dobne granice mogu malo varirati ovisno o različitim čimbenicima pa ih se ne može dogmatizirati.

Uttal i dr. (2006) otkrili su da su djeca u dobi od osam godina sposobna pravilno obraditi informacije dobivene iz „ptičje perspektive”, ali ne mogu kombinirati verbalne 
informacije o prostoru kako bi proizvela kartu. Za razliku od starije djece i odraslih, osmogodišnja djeca primorana su promatrati grafički prikaz prostorne situacije kako bi mogla razumjeti prostorne odnose. Ondracek i Allen (2000) došli su do sličnoga zaključka u svome radu. Iako osmogodišnja djeca očito imaju sposobnost pamćenja opisa, ona ne mogu pretvoriti isti opis u koherentni model ili prikaz toga opisanog prostora.

Drugi radovi pristupaju istraživanju razvoja prostorne percepcije iz suprotne perspektive. DeLoache (1987) je potvrdio razvoj dječje sposobnosti razumijevanja simboličnoga odnosa između karata ili slika i prostora koji bi trebale predstavljati. U jednom eksperimentu, od djeteta je traženo da pronađe predmet (igračku) skriven u prostoriji koristeći kartu ili neki drugi slikoviti vodič. Rezultati su pokazali da trogodišnje dijete može uspješno izvršiti zadatak, odnosno može razumjeti odnos između predmeta i prostorije. Koristeći se slikovitim vodičem, čak su i djeca od dvije i pol godine bila uspješna u određenim okolnostima.

Prostorni koncepti i prostorne informacije mogu se dobiti iz više od jednoga izvora, ali obično se stječu kroz obrazovanje ili iz vlastitoga iskustva (Lane, Carter i Bourke, 2019; Schubert, 2016). Osoba stvara vlastitu sliku prostora u kojem se kreće te stvara subjektivan odnos prema njemu (Siwek, 2011). Prostor koji okružuje pojedinca zatim je opažen s nekoliko općih elemenata, kao što su smjer i udaljenost (Siwek, 2011). Zahvaljujući tim elementima, osoba se može orijentirati u prostoru, a slika percepcije prostora u podsvijesti zapravo je kognitivna (mentalna) karta. Prema autorima Downs i Stea (2011, str. 312) „kognitivno kartiranje je proces koji se sastoji od niza psiholoških preobrazbi, kojima pojedinac stječe, kodira, pohranjuje, podsjeća i dekodira informacije o relativnim lokacijama i atributima pojava u njegovoj svakodnevnoj prostornoj okolini”.

\section{Mentalna karta}

Koncept mentalne karte prvi je put primijenjen u psihologiji, a zbog svoje interdisciplinarnosti, kasnije je korišten i u sociologiji, kartografiji i geografiji (Lloyd, 1989). Geografski pristup konceptu može se objasniti iz perspektive autora Tuana (1975, str. 209), koji mentalnu kartu shvaća kao „posebnu vrstu slike, direktno povezanu s osjetilnim iskustvom” odnosno „Mentalna karta posebna je vrsta slike koja je još manje direktno povezana s osjetilnim iskustvom". Drbohlav (1991, str. 164) opisuje mentalnu kartu kao „grafički (kartografski ili shematski) izraz ljudske slike geografskog prostora, najčešće prema njegovoj kvaliteti ili izgledu”. S druge strane, prema Osmanu (2016), mentalna karta također se može shvatiti kao općeniti pojam koji obuhvaća raznovrsne načine organiziranja prostornoga znanja. Mentalna karta može se zatim razumjeti i kao projekcija prostora u umu pojedinca (u čijem se slučaju ona također može smatrati kognitivnom kartom) te kao kartografski proizvod u obliku grafičkoga prikaza. Takav prikaz onda obuhvaća sliku, u danoj slici prostora, što je subjektivno važno i značajno za pojedinca (Šerý i Šimáček, 2012). S obzirom na odnos pojava prema objektivnoj 
stvarnosti, mentalne karte dijele se na dvije vrste: komparativne i preferencijalne (Gould i White, 1993). Preferencijalna mentalna karta sadrži kvalitativne procjene. Učinak takve mentalne karte ne može se uspoređivati sa stvarnošću zbog toga što se temelji na preferencijama pojedinaca. $S$ druge strane, komparativna mentalna karta (koja se koristi u kontekstu sadašnjega istraživanja) povezana je sa stvarnošću te se stoga njezina točnost i dosljednost sa stvarnošću mogu objektivno procijeniti (Siwek, 2011).

Uttal i dr. (2006) zaključili su u svom istraživanju da sposobnost korištenja karte može pomoći djeci razumjeti i prevladati granice svoje percepcije prostora. Korištenje karte i stvaranje mentalne karte također vodi dijete do spontanoga promišljanja o tome kako se novonastale prostorne informacije mogu predočiti u kartu, koja razvija druge sposobnosti djeteta. Mentalna karta svakog pojedinca razvija se kroz njihov život. Boulding (1956) opisuje tri mogućnosti razvoja razine informacije o okolini. Osoba postupno, najčešće kroz razdoblje puberteta, dobiva informacije o okolini, njezino se znanje produbljuje i dopunjuje raznovrsnim informacijama te se mentalna karta prostora kontinuirano obogaćuje. Abrahamsson (1999) tvrdi da sveobuhvatnost mentalne karte ovisi o količini iskustva s prostorom te opsegu pokretljivosti unutar tog prostora. Faza tijekom koje pojedinac ne dobiva nove informacije te se već stečene informacije samo potvrđuju direktnim iskustvom prostora prema Bouldingu (1956) naziva se nultim razvojem. Ako se iskustvo prostora ne ponavlja, količina informacija dobivena mentalnom kartom postupno se s vremenom smanjuje. Organizacija prostora u umu pomaže nam saznati više o odnosima između osnovnih ljudskih sposobnosti učenja o okolišu i ponašanju ljudi. Mentalne karte pomažu nam saznati više o osnovnim ljudskim sposobnostima učenja o okolišu te pružaju uvid u to kako ljudi predstavljaju okoliš i kako se ponašaju (Kitchin i Blades, 2002).

\section{Cilj istraživanja i istraživačka pitanja}

Izrada slika, grafova ili karata može aktivirati kognitivne sposobnosti učenika (Višnić, Ivanović Bibić, Đukičin Vučković, Ivkov-Džigurski i Konečnik Kotnik, 2017). Poput drugih istraživanja usmjerenih na prikupljanje informacija kroz dječje skice (npr. Ahi, 2017; Bláha i Pastuchová Nováková, 2013; Catling, 1998; Gillespie, 2010; Matthews, 1984b; Schubert, 2014), ovaj rad također odražava važnost dječjega crtanja koje učenicima može pomoći u uspješnijem prolasku kroz obrazovni proces.

U dobi od otprilike šest godina, kognitivna sposobnost djeteta značajno je napredovala i dijete počinje realno doživljavati svijet (Langmeier i Krejčířová, 2006), što se može smatrati prvim preduvjetom za naknadno opisivanje i crtanje stvarnosti. Tek u narednim godinama dijete postupno razvija druge sposobnosti, kao što su apstrakcija, shematizacija itd., koje uvelike utječu na posredni oblik percepcije stvarnosti u obliku mentalne karte. Iz navedenih razloga, u ovo istraživanje bila su uključena samo djeca u dobi od šest ili više godina koja pohađaju standardnu osnovnu školu. Određeni rizik u realizaciji istraživanja mogao je predstavljati značajan udio učenika s posebnim poteškoćama u učenju, kao što je Aspergerov sindrom itd., koji ima i veći utjecaj na 
njihovu prostornu orijentaciju te stvaranje mentalnih karata. Taj je rizik eliminiran dosljednom selekcijom uzorka istraživanja.

Prilikom formuliranja istraživačkih pitanja, autori su se služili starijim radovima prema kojima djeca stvaraju složenije i točnije karte s porastom dobi i iskustva (npr. Piaget i Inhelder, 1967). Međutim, dob možda nije jedini čimbenik u tom procesu. Webley (1981), Montello i sur. (1999), Huynh i sur. (2010) te Anacta i Bartoschek (2014) ukazuju na moguće razlike u izradi mentalnih karata ovisno o spolu. U kontekstu prethodno navedenih studija, glavni je cilj rada doprinijeti postojećem iskustvu u istraživanju stvaranja percepcije prostora u dječjim umovima, razvoju sposobnosti grafičkoga prikazivanja prostora u školskoj dobi te za vrijeme puberteta kroz vlastite crteže mentalnih karata. Može li se potvrditi povezanost između nacrtanoga prikaza prostora i dobi djeteta? Također se postavlja pitanje je li stupanj povezanosti ovih sposobnosti s djetetovim spolom, predstavljen na primjeru Webleya (1981), doista toliko značajan?

\section{Metode}

\section{Pozadina istraživanja}

Teoretski, za ovo istraživanje možemo reći kako je ponajviše vezano uz polje geografske fenomenologije, koje se temelji na proučavanju svakodnevnih praksi pojedinaca $u$ prostoru iz različitih perspektiva (Gregory, Johnston, Pratt, Watts i Whatmore, 2009), u ovom slučaju pojedinci su učenici osnovne škole. Percipirani fenomen je prostor koji svaki učenik promatra na svoj subjektivni način.

Kvalitativno vrednovanje mentalnoga kartiranja prostora, koji je djeci dobro poznat, postala je glavna istraživačka metoda. Prema Frantálu, Bevku, van Veelenu, Hărmănescu i Benediktssonu (2017, str. 238) „mentalno kartiranje vrijedan je alat za razumijevanje kako ljudi percipiraju i odražavaju svoje okruženje... otkriva individualnu spoznaju krajolika, koja je odraz mentalne konstrukcije prostornog razmještaja u memoriji skiciranoj na papiru”. Često spomenuti nedostatak ove metode mentalnoga kartiranja je mogućnost vizualizacije okoline, odnosno, to što na sadržaj mentalne karte može utjecati pamćenje ispitanika (Mark i dr., 1999). Tvrdnju potvrđuju Golbeck i dr. (1986) koji navode da se sposobnost vizualizacije određenoga prostora poboljšava s povećanjem posjeta takvom prostoru. Zbog toga su učenici zamoljeni da nacrtaju krajolik za koji je zajamčeno svakodnevno ponavljanje doživljaja prostora. Osim toga, Lilley (2000) ukazuje na činjenicu kako nastanak mentalne karte nije uvjetovan isključivo sposobnošću ispitanika da razumije krajolik, već mentalna karta predstavlja kreativni proces u kojem su crtačke sposobnosti ispitanika presudne. Zato u ovom istraživanju ni jedan kriterij izravno ne procjenjuje umjetničku vrijednost crteža, a od učenika se nije očekivalo niti tražilo imitiranje stvarnosti preciznošću svojih slika. Unatoč nedostatcima u provođenju istraživanja mentalnih karata, navedena metoda relativno se često koristi jer se smatra pouzdanom za prikupljanje informacija o određenoj okolini (Blades, 1990). Kvalitativna analiza komparativnih mentalnih karata koje su izradili učenici i koje su naknadno vrednovane na temelju nekoliko odabranih kriterija, stoga je postala glavna metoda u realizaciji našega istraživanja. 
U stručnoj literaturi mogu se naći brojni oblici evaulacije mentalnih karata. Klett i Alpaugh (1976) identificirali su mnoštvo obilježja karata koja se mogu vrednovati, poput ljestvice ili perspektive crteža. Harwood i Usher (1999) razvrstali su karte prema pet kriterija: točnost prostornoga rasporeda, udio nacrtanih elemenata (ljestvica), perspektiva rasporeda objekata, razina apstrakcije crteža i način izražavanja simbologije. S druge strane, Lynch (1960) se usredotočio na skupine objekata koje se kontinuirano ponavljaju u mentalnim kartama. Ispitanici pridaju najveću važnost određenim objektima i tako stvaraju sliku geografskoga prostora u gradovima. Grupe objekata podijeljene su u sljedeće skupine: četvrti (npr. stambena područja), staze (npr. ulice), rubovi/granice (barijere kao što su npr. rijeke), čvorovi (npr. željezničke stanice) i znamenitosti (npr. važne građevine). Na temelju tih skupina prema Lynchu, Gillespie (2010) je izradila vlastitu analizu mentalnih karata. U svojem je istraživanju zamijenila skupinu društvenih čvorova socijalizacijom, odnosno bilo kojim pokazateljem ili slikom koji pokazuju interakciju između ljudi. Proširila je vrednovanje mentalnih karata korištenjem dodatnoga kriterija, odnosno praćenjem odnosa djece prema nacrtanom krajoliku. Prema njezinim istraživanjima, dijete razlikuje one elemente koji su doista važni na njegovoj mentalnoj karti, bilo razrađenim detaljima ili naglašavanjem veličine elemenata u odnosu na ostatak skice. Drugi često korišteni kriterij procjene u analizi mentalnih karata je učestalost nacrtanih elemenata. Istraživanja Matthewsa (1984a), Kynčlová, Hudečeka i Bláha (2009) te Bláha i Pastuchová Nováková (2013) tu učestalost koriste za identifikaciju najznačajnijih elemenata koje učenici percipiraju, kao i za identifikaciju određenih specifičnih razlika između pojedinih grupa učenika.

\section{Uzorak istraživanja}

Potrebni podatci (mentalne karte učenika) dobiveni su putem istraživanja u Osnovnoj školi Šumperk, gdje je bilo uključeno ukupno 174 učenika - 104 dječaka i 70 djevojčica (Tablica 1).

\section{Tablica 1.}

Za potrebe evaluacije istraživanja odabrani su razredi, koji su kasnije grupirani u trogodišnje skupine (od prvog do trećeg razreda, od četvrtog do šestog te od sedmog do devetog). Temeljna pretpostavka za ovu podjelu usvojena je prema osnovnim razvojnim fazama ljudskoga života iz ontogenetsko-razvojne psihološke perspektive: mlađa školska dob, starija školska dob i pubertet (Langmeier i Krejčířová, 2006), odnosno razvojne faze prostornoga razmišljanja prema Stückrathu (1963) ili razvoj prostornih sposobnosti prema Piaget i Inhelder (1967), uzimajući u obzir strukturu nacionalnoga obrazovnog sustava. Sposobnost percepcije i reprezentacije pojedinih komponenti geografskoga prostora i veza u njemu značajno se razlikuju između ovih razvojnih faza, odnosno između dobnih skupina. Postupno dolazi do pomaka od izrazito egocentričnoga razumijevanja prostora sa slučajnim rasporedom njegovih dijelova, bez razumijevanja odnosa, pravilne raspodjele i proporcije elemenata, do 
reprezentacije odozgo, sa značajno poboljšanim razumijevanjem položaja, veličina, udaljenosti i proporcionalnosti (Catling, 1978; Stückrath, 1963).

Istraživanje je provedeno početkom 2015. godine. U prvoj fazi pristupilo se ravnatelju sa zahtjevom da se omogući provedba istraživanja, dogovoreni su određeni datumi $s$ učiteljima razredne nastave i istraživanje nije bilo usmjereno na određeni školski predmet.

\section{Specifikacija zadatka istraživanja}

Prvo je provedeno pilot-istraživanje u kojem je sudjelovalo 15 učenika u dobi od 6 do 12 godina. Učenici su ispitani o njihovom poznavanju različitih dijelova grada. Zatim su trebali nacrtati karte tih lokaliteta. Prethodno je odlučeno da rezultati ovoga pilota istraživanja neće biti uključeni u kasnije vrednovanje glavnoga istraživanja, tako da je bilo moguće voditi pilot-istraživanje na kvalitetniji način (mogućnost razgovora s djecom i postavljanje dodatnih pitanja za provjeru znanja o različitim lokalitetima te sposobnošću crtanja željenih elemenata). Prvobitna namjera bila je procijeniti prostornu percepciju učenika na temelju mentalne karte gradskoga parka. Budući da se nalazi u blizini škole, postojala je pretpostavka da je većina učenika već posjetila ovaj park. Međutim, pokazalo se da samo mali postotak učenika poznaje ovaj park, a nisu poznavali ni druge izvorno odabrane lokacije. Glavno istraživanje bilo bi pod velikim utjecajem ove spoznaje, stoga je bilo potrebno promijeniti odabranu lokaciju. U konačnici je odlučeno da će učenici crtati dvorište svoje škole, što im je omogućilo da nacrtaju okruženje koje je dobro poznato iz ponavljajućega, zapravo, gotovo svakodnevnoga prostornog doživljaja. Na temelju pilot-istraživanja definirano je i vrijeme potrebno za provođenje istraživanja u razredima.

Unutar glavnoga istraživanja učenici su zamoljeni da nacrtaju mentalne karte prostornoga uređenja okruženja škole. Zadatak za crtanje mentalne karte glasio je ovako: „Nacrtajte ono što se nalazi oko vaše škole što bolje možete; pokušajte mi pokazati da poznajete ovaj prostor." Osim toga, učenici su bili upućeni da detaljno opišu nacrtane elemente. Učenicima nisu dani nikakvi konkretni odgovori na njihova dodatna pitanja, tako da je koncept samog zadatka bio na učenicima. Nije određeno vremensko ograničenje za crtanje mentalne karte. Međutim, istraživanje je bilo ograničeno na maksimalno 45 minuta koliko traje jedan školski sat. Kako bi se osiguralo da format papira ne utječe na rezultat, svim je učenicima podijeljen standardni list bijeloga A4 papira. Na temelju pretpostavki prikazanoga istraživanja, priložen je jednostavan upitnik na listu na kojem je trebalo nacrtati mentalnu kartu. Od učenika se tražilo da popune nekoliko osnovnih identifikatora koji bi se mogli koristiti za praćenje utjecaja individualnih obilježja ispitanika na karakteristike njihovih mentalnih karata. Cijeli upitnik bio je potpuno anoniman te je sadržavao podatke o spolu, dobi i stalnom boravku.

\section{Analiza mentalnih karata}

Evaluacija mentalnih karata korištenih u ovom radu temelji se na klasifikacijskim shemama opisanim u slično orijentiranim istraživanjima (vidi gore). Kako bi se 
identificirale zajedničke i različite značajke mentalnih karata učenika, njihova je procjena izvršena na temelju četrnaest kriterija (Tablica 2) od kojih su tri glavna kriterija dodatno, detaljnije analizirana. Odabrani kriteriji omogućuju procjenu razvoja osnovnih kontura koncepta prostora. $S$ tog stajališta, drugi su kriteriji uglavnom komplementarne informacije, kao i informacije o načinu na koji su karte izrađene.

\section{Tablica 2.}

Broj i fokus kriterija ocjenjivanja osmišljeni su tako da obuhvate što je moguće više podataka iz skica. Cilj vrednovanja bio je obuhvatiti kvalitativne i kvantitativne promjene u percepciji prostora povezane s razvojem pojedinca - način na koji pojedinac pretvara svoju mentalnu sliku u kartu te koje elemente on/ona smatra ključnim u prostoru i stoga također prikladnim za crtanje na mentalnoj karti.

U smislu statističke obrade, značajnu ulogu imale su osnovne karakteristike učenika, kao što su dob (ili stupanj iskustva) i spol te također i tri kriterija odabrana za procjenu djelomičnih aspekata dobivenih mentalnih karata. Na temelju prvoga odabranog kriterija - broja korištenih perspektiva - karte su bile dihotomski podijeljene u skice koje su sadržavale samo jednu perspektivu nacrtanih objekata i one skice gdje su objekti prikazani u više perspektiva. Prema drugom kriteriju - perspektivi koja se koristi za zgrade - procijenjen je određeni prevladavajući način crtanja zgrada, tj. bočni, kosi ili pogled odozgo. Treći kriterij - razina shematizacije - kategorizira karte na one koje su pokazale nizak, srednji ili visok stupanj shematizacije objekata koji su nacrtani (Slika 1). Zbog prirode podataka korišteni su Cramerov koeficijent, Spearmanov koeficijent i Phi koeficijent za procjenu međuovisnosti.

Slika 1.

\section{Rezultati}

$\mathrm{Na}$ temelju provedenoga istraživanja postoji značajna razlika u prikazivanju prostora među učenicima različitih dobnih skupina. Broj korištenih perspektiva bio je prvi kriterij procjene. Ukupno 106 učenika (61 \% svih sudionika) nacrtalo je kartu iz jedne perspektive. U odnosu na kategorije kriterija „broj perspektiva” koje su praćene, to je bio prevladavajući način koji se koristio za prikazivanje perspektive. Ako se pobliže razmotri, može se zaključiti da ga je koristilo $66 \%$ učenika od prvoga do trećega razreda, dok je među učenicima od četvrtoga do šestoga razreda ova kategorija zabilježena u $61 \%$ slučajeva, a u grupi najstarijih učenika rezultati su manji za pet posto. Prema spolu, u ovu kategoriju ulaze 71 dječak ( $68 \%$ od svih dječaka koji su sudjelovali) i 35 djevojčica (50\% od svih djevojčica koje su sudjelovale).

Najčešći način prikazivanja zgrada bio je tlocrt koji je odabralo 103 učenika (više od $59 \%$ svih sudionika). S druge strane, samo je oko $5 \%$ učenika odabralo kosi pogled (bokocrt) za odabrani prostor. Tlocrt se najviše pojavljivao kod učenika od sedmoga do devetoga razreda, točnije u $94 \%$ slučajeva, dok je kod učenika od četvrtoga do šestog razreda udio iznosio $59 \%$ te u najmlađoj skupini samo $20 \%$. Kada se uzme u 
obzir spol, 65 dječaka ( $63 \%$ od svih) i 38 djevojčica ( $54 \%$ od svih djevojčica koje su sudjelovale) odabralo je tlocrt.

Iako gotovo 37 \% sudionika u istraživanju pripada najstarijoj dobnoj skupini, s vrlo velikim udjelom učenika s visokim stupnjem shematizacije crteža (84 \%), udio ove kategorije u cjelini bio je manji od $22 \%$. Razina shematizacije s najvećom zastupljenošću bila je srednja, koju je odabralo 84 učenika ( $48 \%$ svih sudionika). Iz perspektive spolova, shematska razina može se ocijeniti na sljedeći način: ukupno 24 dječaka ( $23 \%$ svih dječaka koji su sudjelovali) i 28 djevojčica ( $40 \%$ svih djevojčica koje su sudjelovale) izradili su karte s niskom razinom shematizacije. Visoka razina shematizacije zabilježena je kod približno istog udjela dječaka (27 \%), dok je kod djevojčica taj udio dramatično pao na $14 \%$.

Izračunate vrijednosti koeficijenata (i p-vrijednosti), na temelju kojih smo procijenili snagu i statističku značajnost ovisnosti između pojedinih karakteristika učenika i odabranih kriterija za procjenu mentalnih karata, prikazane su u Tablici 3.

Tablica 3.

Statistički značajne zavisnosti o razini značajnosti .05 mogu se vidjeti samo u pet entiteta; međutim, snaga zavisnosti značajno se razlikuje u tim slučajevima. S tim u vezi, zabilježena je najjača zavisnost razine shematizacije i dobi učenika (odnosno stupnja stečenoga iskustva), nakon čega slijedi korištena perspektiva i opet, starost učenika. S druge strane, ovisnost između roda i odabranih kriterija čini se prilično slabom. S ove točke gledišta, broj nacrtanih perspektiva jedini je kriterij ocijenjen kao značajan, jer su karte, koje su nacrtali dječaci, pokazale veći stupanj shematizacije od karata koje su izradile djevojčice. Međutim, ova statistička razlika uočena je samo u drugoj dobnoj skupini.

\section{Rasprava i zaključci}

U sveobuhvatnom pogledu mentalnih karata, koje su napravili učenici, moguće je identificirati značajnu transformaciju sposobnosti učenika između šeste i petnaeste godine u stvaranju mentalnih karata, odnosno prikaz i percepciju pojedinih elemenata prostora, što je već bilo spomenuto, npr. u radu autora Piageta i Inheldera (1967) ili Catlinga (1978). Možemo naći nekoliko razloga za to. Uz značajan razvoj psihičkoga aspekta djece u promatranom razdoblju, što je isto povezano s postupnim razvojem sposobnosti za apstrakciju, shematizaciju i generalizaciju, prisutan je još jedan uzrok u postupnom usmjerenom upoznavanju učenika s geografskim prostorom i kartom kao najčešće korištenim sredstvom za njegovo opisivanje na školskim predavanjima od četvrtoga (početak projekcijske faze) te još značajnije od šestoga (omogućujući početak euklidske faze) razreda. Ta je promjena vidljiva na Slici 2. Usporedbom nalaza ovog rada i rada Piageta i Inheldera (1967) uočene su razlike u deklariranoj dobi kada bi djeca trebala prijeći iz jedne faze u drugu. Prema Piagetu i Inhelderu (1967) djeca bi trebala prijeći na sljedeću fazu razvoja otprilike jednu do dvije godine ranije nego što 
je utvrđeno ovim istraživanjem. Razlozi za to mogu biti brojni, ali oni se najvjerojatnije manifestiraju specifičnostima formalnoga obrazovnog sustava, uključujući različit pristup geografskom kurikulu.

Slika 2.

Istraživanje pokazuje da, ovisno o dobi učenika, stupanj shematizacije slika značajno raste te se vrste perspektive učenika u crtanju zgrada mijenjaju. Dok najmlađi učenici, od prvoga do trećega razreda, u svojim crtežima često više vole pogled odozgo na zgrade, s povećanjem broja godina, pogled odozgo počinje prevladavati te kod učenika devetoga razreda dominira. Ovaj zaključak potvrđuje jednu od glavnih otkrića, od primjerice Gerbera (1981) o izraženoj povezanosti između razvoja apstrakcije i sposobnosti crtanja preko pogleda odozgo. Zanimljiv nalaz nekih autora, kao što su Matthews (1984b), Liben i Downs (1994) te Catling (1998), o nedosljednosti prikaza prostorne perspektive među učenicima iste dobi kroz crteže tek je djelomično potvrđena sadašnjim istraživanjem i to kod djevojčica od četvrtoga do šestoga razreda (od 9 do 11 godina).

Slično tome (ali ne i tako značajno), ustanovljena je izravna ovisnost između rasta dobi učenika i razine shematizacije crteža. Kao u prethodnom slučaju, ova spoznaja može se opravdati postupnom razvoju sposobnosti apstrakcije, kao što je napomenuo Gerber (1981). Međutim, u sadašnjem istraživanju utvrđena je značajna neujednačenost razvoja razine shematizacije pri čemu je uočljiva velika razlika između prvoga i četvrtoga te petoga i devetoga razreda. Dublje proučavanje državnih kurikula i školskih nastavnih planova otkrivaju izravnu poveznicu između povećanja razine shematizacije između četvrtoga i petoga razreda s početkom sustavnoga geografskog obrazovanja, koje, u češkom obrazovnom sustavu, najčešće počinje u tom razdoblju. S rastućim ciljanim razvojem geografskih i kartografskih kompetencija učenika tijekom šestoga do devetoga razreda, kao što su spomenuli Hanus i Marada (2013), ili neznatno Knecht i Hofmann (2013), raste i razina shematizacije crteža.

Što se tiče ovisnosti promatranih kriterija o spolu djeteta, rezultati nisu toliko statistički značajni i u nekim slučajevima, u velikoj mjeri ne potvrđuju zaključke koje su donijeli autori Webley (1981), Huynh i dr. (2010) i drugih istraživanja. Međutim, potrebno je naglasiti, npr. kako je Webley (1981) svoje istraživanje provodio na skupini osmogodišnjaka, dok su Huynh i dr. (2010) svoje istraživanje temeljili na razlikama u spolu odraslih. Jedini kriterij, prema kojemu je ovisnost o spolu statistički značajna, razina je shematizacije, gdje crteži dječaka pokazuju veći stupanj shematizacije nego crteži djevojčica. Ipak, ovaj zaključak primjenjuje se jedino ako se uzme cjelokupni uzorak istraživanja. U slučaju dubljega unutarnjeg ispitivanja pojedinih dobnih skupina, ne postoje značajne statističke razlike u stupnju shematizacije između dječaka i djevojčica. Detaljnije proučavanje mogućih razlika u razini shematizacije među djevojčicama i dječacima određenih dobnih skupina ne potvrđuje značajne statističke ovisnosti. S obzirom na razlike u spolu, zanimljiv je kriterij broja perspektive unutar 
određenih dobnih skupina. Dok, $\mathrm{s}$ jedne strane nije potvrđena značajna ovisnost u dvjema drugim vanjskim grupama, ovisnost je bila od iznimne važnosti za srednju skupinu (od četvrtog do šestog razreda). Utvrđeno je da dječaci u toj grupi koriste samo jednu perspektivu tijekom crtanja, dok djevojčice teže korištenju više perspektiva.

Sposobnost crtanja jednostavnih mentalnih karata dobro poznatoga prostora, značajno se mijenja među djecom tijekom njihovih školskih godina. Moguće je vidjeti promjenu od skica s niskom razinom shematizacije koje najvećim dijelom sadrže bočne prikaze predmeta nacrtanih od strane šestogodišnje učenice, do skica s visokom razinom shematizacije i izrazitim dominantnim pogledom odozgo na zgrade nacrtanih od strane učenika u razdoblju puberteta. Ova promjena posljedica je, konkretno, značajnoga razvoja nekih psihičkih funkcija djeteta, također i postupnoga stjecanja novih geografskih i kartografskih kompetencija unutar formalnoga obrazovanja. Takvi su zaključci od pomoći učiteljima kada je riječ o odabiru i oblikovanju ciljeva geografskoga obrazovanja za svaki razred, kao i za bolje prepoznavanje naknadnoga ispunjavanja takvih ciljeva od strane učenika. 